\title{
Situating Border Control: Unpacking Spain's SIVE border surveillance assemblage
}

A stream of fuzzy walky-talky noise and intermittent alarms welcomes me to the Guardia Civil's control room above the border crossing point at El Tarajal, Ceuta. Despite the location, the guards' attention inside the room is not fixed on the multitude of cars and pedestrians queuing to gain access to the Spanish principality from the nearby Moroccan countryside. Instead, their focus is on the five mile stretch of double border fencing which separates the enclave from Morocco, as well as on the ships travelling through the Strait of Gibraltar and the fishing vessels in Fnideq bay. I have come here predominantly to see Spain's SIVE (Sistema Integrado de Vigilancia del Exterior) surveillance system, a complex assemblage of radar technology, high-tech cameras, vessel $\mathrm{AIS}^{1}$ and border guards in action. SIVE is designed to give the Guardia Civil constant 'real time' surveillance capabilities over Spain's territorial waters and borders (Guardia Civil 2008). It has also largely been credited for the 'successful' shift in boat migration away from Spain (Guardia Civil 2008) and was used by Frontex as the blueprint for its EUROSUR surveillance system (Andersson 2014; Godeneau 2014; López-Sala 2015).

In the control room, SIVE is being operated by Juan, ${ }^{2}$ a young, bespectacled border guard sitting at the quieter end of the room, his eyes focused on 
a computer monitor showing a radar image of the marine area surrounding Ceuta. "I'd like to give you a full demonstration of the system," he says motioning to a blank computer screen, "but today they are installing a new software system for the camera, so only the radar is operational right now." Nevertheless, Juan takes me through the SIVE system and how it is employed in Ceuta. Returning to the radar monitor, Juan points to the various yellow lines that criss-cross across the screen: "We call these the 'Tracks'," he continues, "they represent the current location of a vessel and how far it has travelled during the last five minutes." The border guards use the radar system to look for vessels with 'suspicious' Tracks and then obtain an optical image of the vessel using the camera.

On the noisier side of the room sits another border guard, noticeably busier than Juan, speedily operating an array of buttons and joy sticks in front of another bank of monitors. Standing behind him is his supervisor, dressed in civilian clothes, who appears to have been called in on his day-off. "It's very windy today", explains the supervisor, "it's tripping all the sensors along the fence. And on top of that, today the gardeners are also clearing the area in front of it!" At the sound of each alarm, the guard punches the button that operates the camera nearest the tripped sensor and pans the area searching for what might have been the cause. Upon spotting a gardener he deactivates the alarm. Other times he waits to see if it might have been more than a gardener or the wind, occasionally he directs 
guards along the fence to check a specific area where he is uncertain. Meanwhile, the walkie-talkie chatter coming back from the guards at the fence confirms the lack of suspicious activity at each alarm site. "We have to move fast", says the supervisor with one eye still focused on the screens, "the fences only slow them down. We need to get to them before they make it across."

$12 \mathrm{pm}$ on a hillside overlooking both the harbour and the border fence between Ceuta and Morocco. While the fence might be brightly lit, the rest of the landscape is pitch black. I'm sitting inside what I had at first thought was an abandoned Volkswagen people carrier, but which later transpired to be one of the Guardia Civil's night patrol units, complete with a mounted infrared camera. Called 'búhos' (Spanish for owl), three units are located in stationary positions at key vantage points along the fence. The main task for the guards of the búhos is to monitor the Moroccan side of the border for migrants hoping to climb the fence. Their other task, however, is to support the SIVE system by detecting small migrant boats (called 'pateras') - especially in the area of Benzú on the Western coast of Ceuta where there is no radar coverage. A minimum of two more units (it transpires that the men from the third unit are on holiday) are equipped with less-powerful, handheld thermal cameras and flashlights. These secondary mobile units act as fast-response units whose main task is to track groups 
of migrants that have been spotted by the larger cameras and to point out their location to the Moroccan guards on the opposite side.

I watch as Miguel, the guard currently on duty in the stationary unit, uses his joystick to pan around the vast area that he has been tasked with patrolling. Staring at the bright screen which inverses black with white, one can almost forget the darkness outside the Volkswagen. Despite the artificial brightness of the world on the computer screen, however, objects that would easily be discernible with the naked eye during the day take on a fuzzy form through the camera lens at night. To an untrained eye like mine the entire landscape appears utterly strange. Suddenly Miguel spots movement in the top-right corner of the screen. By using the camera's telescopic zoom he attempts to get a clearer picture of what has alarmed him. Miguel clicks his tongue and points towards a small fuzzy form on the screen. "Just a Moroccan guard on patrol," he says, zooming out and resuming his video-game like surveillance.

\section{INTRODUCTION}

This article builds on the 'practice turn' in border studies by critically engaging assemblage theory as a means of 'unboxing' European maritime 
surveillance. As the opening narratives suggest, maritime border security is dependent on an array of objects, bodies, materials and cultures that must consistently work together if the systems that produce border surveillance are to hold their shape. My aim is to put assemblage theory to work in order to foreground the messiness of producing (in)security such that a more productive account of the everyday geopolitics of the border can be made visible. Central to this account are the untidy alliances on which security systems are based, the multiplicity of the assemblages involved, and the "rhythmic turbulence of the material world" (Steinberg and Peters 2015, 248). By focusing on the ways in which border guards 'see' and act upon the volatile borderspace through various surveillance technologies, the article seeks out the limits of the state's surveillant powers and the 'cracks' within its socio-technical systems of control.

Specifically, my focus is on 'un-boxing' Spain's SIVE maritime surveillance system: a complex assemblage of radar technology, high-tech thermal cameras, vessel automatic identification systems (AIS) and border guards. Described by the Guardia Civil as an "early detection system giving the possibility of transmitting, in real time" (Guardia Civil 2008, 17), SIVE was developed in order to modernise the Guardia Civil's previous methods of coastal surveillance, which were "based on the masse use of persons" and deemed insufficient for protecting the Spanish coast (Guardia Civil 2008, 29). The initial SIVE design was aimed primarily at tackling smuggler gangs, 
who were using speedboats to dump drugs on the Spanish coast. As a result the system was designed specifically to detect small vessels travelling at fast speeds, regardless of the weather conditions (see Figure 1). Following the increase of sub-Saharan migrants attempting to reach Europe via Spain in the early 2000s, however, the Guardia Civil altered the stated aims of SIVE to include the detection and search \& rescue of small migrant boats (known as pateras) (Guardia Civil 2008). As a result of increasing SIVE's scope, moreover, the Guardia Civil received over €53 million from the EU External Borders Fund between 2007 and 2013 in order to expand the SIVE network along the Spanish coast to help meet its "responsibilities in the control of the external borders [of the EU]" - thus bringing total investment in the system to over two hundred million euros (EC IP/08/1849, 1; Guardia Civil 2008). ${ }^{3}$

In 'un-boxing' SIVE I aim to critique the supposedly ever-vigilant surveillance and life-saving capabilities of the SIVE surveillance system by foregrounding the interactions between the various human and machine elements of SIVE. While claims that maritime surveillance technologies save lives have been criticised previously (e.g. Heller and Jones 2014; Rijpma and Vermeulen 2015; Pallister-Wilkins 2015; Bellanova and Duez 2016), few have taken the everyday performances of border guards and the materialities of the borderspace as a methodological starting point for their research. Moreover, the formal position of the EU remains that maritime surveillance technologies 
do save lives in the Mediterranean, that they are no longer used for "push back' operations and, increasingly, that they are integral to solving 'Europe's migration crisis' (European Parliament and Council of the European Union, 2013), despite the arguments of the civil society to the contrary (Alarm Phone 2017). An increasing number of studies, however, are beginning to focus on the everyday performances of the EU's EUROSUR 'near real time' surveillance system, however, though its capabilities are still developing. Both Tazzioli (2016) and Dijstelbloem et al (2017) highlight how, for a system which supposedly functions in 'near real time', EUROSUR is still a slow system - its vision capabilities on interactive maps being predominantly used to create visualisations of historic incidents in order to more accurately predict future ones. Due to the speed with which it has been designed to operate, however, SIVE is in this respect very different from EUROSUR. Nonetheless, the war for speed remains an issue for the Guardia Civil and will be discussed in this article.

In the following section I set out the ways in which assemblage theory can contribute to the newly-established 'practice turn' in border studies. I argue that assemblage theory offers the opportunity of situating those who 'do surveillance' within large socio-technical systems, while also recognising the agency of matter and the need to focus on interactions rather than properties. Thereafter I focus on how vision is produced amid the everyday realities of the borderspace. I detail how, as well as negotiating the use 
of the SIVE technologies, Spanish border guards must contend with the actions of migrants, smugglers and the geophysical environment. In the third empirical section, I discuss the ways in which the geopolitical gaze produced by SIVE is susceptible both to the rebellion of its actors, as well as the volatile environment of the borderspace itself.

Finally, a note on method. Gaining access to both the borderspace and to those employed to control it can be challenging for researchers (CôtéBoucher et al 2014), and my experiences of this have been no different. My initial requests to conduct a lengthy participant observation of the SIVE control centres was, unsurprisingly, rebuffed. Nevertheless, I was eventually granted access to the SIVE control stations of Ceuta and Algeciras on three separate occasions, as well as once to the mobile búho at the border fence. Aside from my first visit to the SIVE control station in October 2013 , these visits took place in the summer of 2014 . On these occasions I was largely left free to observe the border guards and to conduct unstructured interviews with them as they worked. Semi-structured interviews were also conducted with the on-site technician in Algeciras, as well as a Guardia Civil officer in Ceuta. The paper also draws from secondary material published by the Guardia Civil to promote the successes of SIVE. Though my time spent at the SIVE stations was short, I have nonetheless been able to gain an insight into the situated experiences of the Guardia Civil border guards as perform Spain's maritime border through SIVE. 


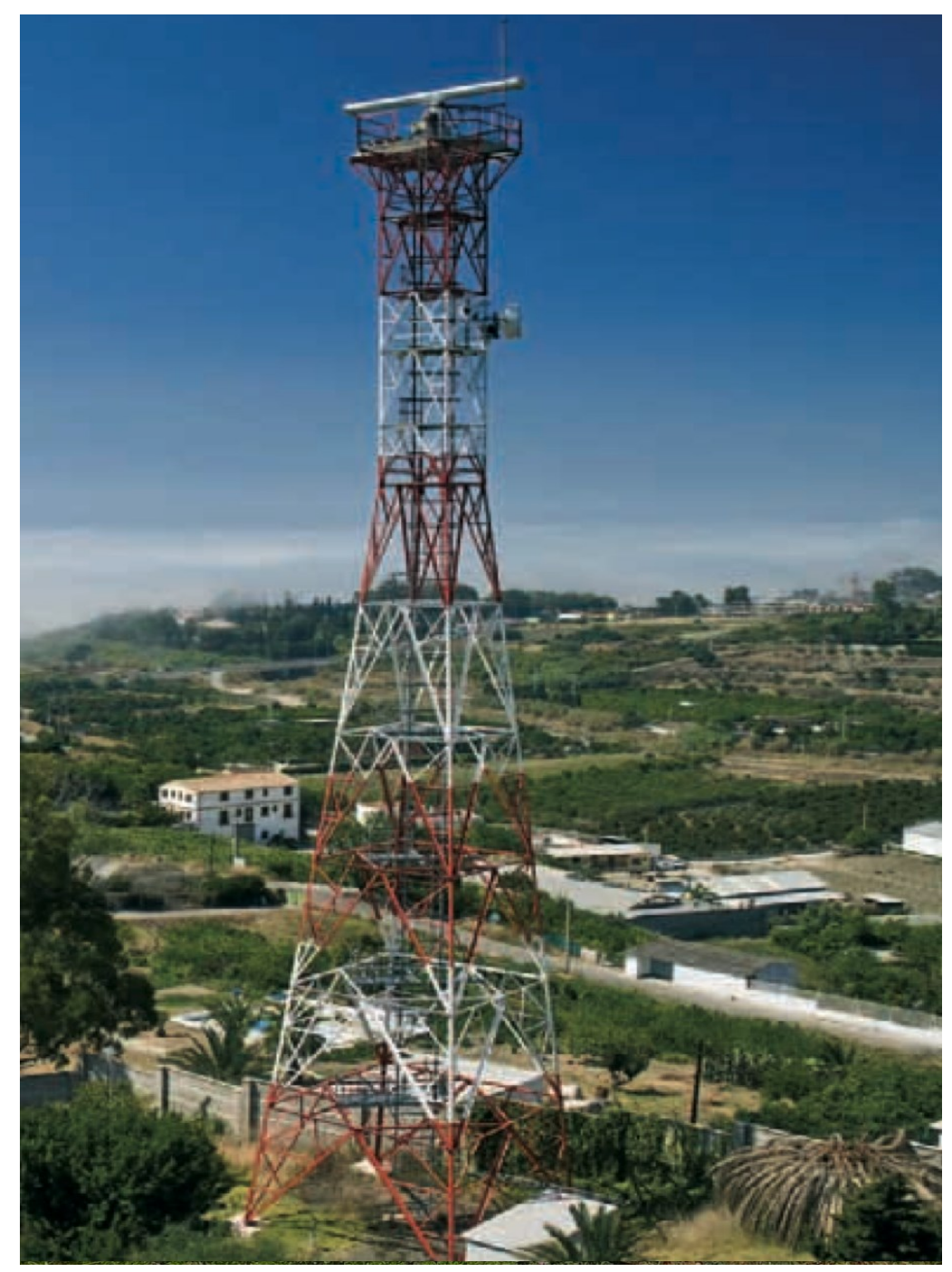

Figure 1 shows the SIVE radar tower protecting the landscape from what might lurk in the bank of encroaching fog. Original caption reads: "A bank of fog covering the coast of Estepona (Málaga) straight in front of a sensor station" (Guardia Civil, 2009, 111). Published with the permission of the Guardia Civil.

\section{THE BORDER AS ASSEMBLAGE}

The diffusion of the border beyond and between national lines has necessitated a reconceptualising of borders to take account of the fluidity of what had previously predominantly been thought of as static entities tied 
down to the extremities of territory. Parker and Vaughan-Williams (2012, 729), especially, have called for critical border studies to "shift from the concept of the border to the notion of bordering practice; and the adoption of the lens of performance through which bordering practices are produced and reproduced." Similarly the term 'borderscapes' has been adopted in order to capture the complexity of the interactions through which border landscapes are continuously being (re)produced (Rajaram and Grundy-Warr 2007). The landscapes concept, moreover, re-centres attention on the mundane and emphasises the need to 'humanise' borders (Brambilla 2015). This conceptual shift in border studies from understanding borders as fixed lines to a combination of social, cultural and political processes has, therefore, presented scholars with a myriad of new questions. Alongside the obvious question of 'where is the border?' arises, amongst others, the apparently simple question 'who borders?' (Johnson et al 2011). As Rumford (2006) and Côté-Boucher et al (2014) argue, 'borderwork' has been delegated to an ever-growing list of local, transnational and private actors outside the state apparatus; these include airline staff, private security firms, software developers, risk consultants, engineers, designers and systems experts (Bigo 2002; Walters 2006; Vukov and Sheller 2013). Following Parker and VaughanWilliams' $(2009,2012)$ push towards studying borders as practice, therefore, we must then also ask 'how do they border?' and find the methods for answering such questions. 
Despite these repeated calls to 'humanise borders' and to focus on the politics of the everyday, however, such has been the concern with the global extent of the border assemblage and the consequences of its incessant creep on a macro scale, that a recent edition in Security Dialogue highlighted the need to re-engage with the 'practice turn' through empirical material focusing on the experiences of border agents in the field (CôtéBoucher et al 2014). Bigo $(2014,211)$, in particular, details how attempts to understand the (in)securitisation of European border control frequently suffer from a lack of "attention to the dispositions of the agents and the contexts" which form a crucial part of the geographies of border control. Similarly, while scholars have focused on the digitisation of the border through biometric technologies (see for example Amoore 2006, 2009; Ajana 2013), Amicelle et al (2015) argue that greater attention needs to be paid to the socio-technical (and material) qualities of other security devices and the ways in which the border is performed on a daily basis by their use. Furthermore, Amicelle et al (2015) urge border scholars to acknowledge the (social) contexts in which security devices are deployed and how this shapes or constrains the deployment of these devices. Here I propose assemblage theory as a possible means through which the embodied experiences of doing security can be held in productive tension with nonhuman agency and an attentiveness to context. 
Assemblage theory, following Deleuze and Guattari's (1987) work on agencement, offers a non-dualistic approach in which society can be viewed as rhizomatic, nodal networks that come together and fall apart, rather than as a series of static wholes (DeLanda 2006). There has been a propensity in border studies, however, to utilise assemblage theory predominantly as a means of conceptualising the pervasiveness of the modern border and the ways in which it makes connections across topological space. Graham (2011, 132), for example, writes that there will be a point at which borders will no longer be geophysical lines and filters and states, becoming instead "increasingly interoperable assemblages of control technologies strung out across the world's infrastructures, circulations, cities, and bodies". Other examples of similarly 'big things' (Jacobs 2006) related to the border that are viewed through the lens of assemblage theory in border studies include the global 'circulation assemblage' (Salter 2013), Andersson's (2016) 'illegality industry' as assemblage, Europe's 'border-work' of fluid mechanisms and actors (Bialasiewicz 2012) and Haggerty and Ericson's (2000) 'surveillant assemblage'. In each of these cases assemblage adds something valuable to the analysis beyond simply demonstrating the scale and interconnectedness of the network. For Salter (2013) and Bialasiewicz (2012), for example, thinking of the global mobility regime and EUrope's border regime as assemblages allows for accounts of the disaggregation of the respective 
systems - neither assemblage can be considered governed by a single overriding logic or dominated by one particular group.

There is, however, also the possibility of going smaller - both in terms of the size of the assemblage and the scale at which it is analysed. An assemblage is, after all, any ad-hoc grouping of any diverse elements that have a co-functioning together (Bennett 2010). In an analysis of a steel plant in the UK, for example, Swanton (2013) demonstrates how otherwise marginalised practices of health and safety, retrofitting and maintenance are vital to understanding how steel is produced - or how production can spectacularly fail. Meanwhile Williams (2011) considers military Unmanned Aerial Vehicles as assemblages for the purpose of questioning the systems' ability to provide 'more-than-human' vision while human elements remain in the network. Williams' (2011) work, therefore, demonstrates how assemblage theory can be used to focus on the performances of one set of actors (in this case the human UAV pilots) and their relations to the other actors within the assemblage (i.e. cameras, screens and joysticks). This focus on the interactions of technologies, materials and humans points to a central tenet of assemblage theory, which is that it "reorients our approach to phenomena by insisting on the autonomy of component parts" (Anderson et al 2012, 177). Agency, therefore, is located in both the human and nonhuman actors with in the assemblage (Bennett 2010). A consequence of this autonomy for Swanton (2013) is that the production of steel is no 
longer guaranteed from the steel plant; instead it is an achievement of socio-material processes which can also fall apart. In context of SIVE, therefore, the production of (in)security is not treated as a given simply because of the assembled presence of various security actors. Moreover the focus of my analysis in the following sections will be predominantly on the interactions between the component parts of SIVE, rather than their individual properties.

Another consequence of the ontological shift brought about by a focus on the relations between actors is an attendance to the importance of multiplicity (Sohn 2015). In particular, assemblage foregrounds the constant, diffuse and tangled effort that goes into the assembling and re-assembling of sociotechnical systems and socio-material practices. Assemblage, therefore, "emphasises spatiality and temporality: elements are drawn together at a particular conjuncture only to disperse or realign, and the shape shifts" (Anderson and McFarlane 2011, p124-5). In other words, if the component parts of an assemblage subsist independently from each other and can be regularly subtracted or added to the whole, then there is no 'core essence' to an assemblage and nor are the various elements akin to pieces of a jigsaw puzzle (Nail 2017). What this requires from border studies and security analyses, therefore, is a conceptual shift that takes account of the dynamism of the actors which comprise surveillance systems such as SIVE. 
As a result, the contours of SIVE itself are considered blurred rather than static as new actors become drawn in and are lashed together.

Yet while these new additions might be moved, changed and made to act, power is neither exerted upon the assemblage 'from above' nor by one particular actor upon the rest. Instead, power "must be understood as distributed among the various components of that assemblage, human and non-human" (Dittmer 2014, 389). Entities, moreover, are never fully actualised within the relations of the assemblage (Anderson et al 2012), their properties only partially encountered and incorporated (Shaw 2012). As a result, there is no guarantee that actors will remain 'loyal' to their counterparts within the assemblage, or that they will react predictably to contextual changes or the addition of new actors (Bennett 2010). Even objects, write Meehan et al (2013), can counteract the assumed aims of the assemblage within which they are located through acts of refusal and technological rebellion. By viewing power distributed amongst numerous actors, therefore, assemblage theory follows on from feminist geopolitics by eschewing state-centric analyses of geopolitics in which only the 'elites' have voices that matter (Dittmer 2014; see Secor 2001; Hyndman 2004).

Finally, assemblage theory also attends to Amicelle et als (2015) call for a focus on the 'contexts' in which security devices are deployed - though context in this case is extended to mean the physical environment, as well as the social. Indeed Elden (in Steinberg and Peters 2015) notes how the 'geo' in 
geopolitics usually refers to 'space' or 'the global', as opposed to 'the Earth' upon which we stand. As a result, the material qualities of territory are often written out of geopolitical narratives and analyses of border security (Boyce 2016). Allied with recent work on material politics (e.g. Barry 2014; Slesinger 2018) and post-humanist political ecologies (e.g. Sundberg 2011; Boyce 2016), therefore, a central analytical starting point to this paper is that neither the material nor the (bio)physical elements that form part of the borderspace should be considered stable foundations upon which (geo)politics takes place. Rather, the series of unpredictable dynamic forcings that constitute the geophysical are integral to the unfolding of political controversies that concern the border (see Dittmer 2014; Steinberg and Peters 2015). In the context of SIVE, especially, performing the border amidst the ever-changeable environment produces a number of challenges both for the human and non-human elements of the system. Indeed the 'things' that appear in the guards' scopes are fleeting, ambiguous and more-than-single (see Walters 2014); their partialities further complicating the interactions between the elements within the SIVE assemblage. The borderspace itself, therefore, can be seen to resist capture by the SIVE vision technologies.

\section{FACT OR FRICTION?}

The local geography of Morocco and southern Spain offers significant challenges to migrants attempting to make the covert crossing either to Ceuta or across the Strait to mainland Spain. Strong currents and waves 
mean that boats can drift at sea for days as migrants often attempt to paddle to Ceuta or use old engines which are prone to cutting out. The occasionally rough conditions can also easily sink an overcrowded wooden fishing boat or soft-hulled zodiac vessel, while the (sometimes total) cloudcover can obscure the coastal lights used by the migrants as reference points for Europe. On the land, too, the environment in Ceuta appears to favour the Guardia Civil. The border fences are surrounded by rocky terrain on the Moroccan side, which is used only by farmers allowing their flocks to graze. Moreover, the Spanish side of the fence has been designated as a 'no-go zone', giving the Guardia Civil the sole use of the tarmac road which runs alongside the fence - thus significantly reducing the 'friction of distance' (Scott 2009) offered by the rough landscape.

For the border guard charged with monitoring the border at night from the mobile infrared camera station, however, the rugged biophysical materialities of the borderspace also pose a significant challenge to their watchfulness (see Boyce 2016). On the screen a human will appear as a black, pixelated shape that is still vaguely-humanoid. Surprisingly, Miguel reckoned he could still distinguish the difference between a human and another animal at a distance of about ten kilometres. Under poor climatic conditions, however, the non-human elements of the terrain can escape political capture and impede the guards' attempts at controlling the borderspace by increasing the 'friction' of the terrain. In humid conditions, for example, the pixelated 
shapes become even less distinct - meaning that the point at which Miguel can distinguish a crouching human from a resting goat can be reduced to just four kilometres. Similarly, if the temperature during the day has been particularly hot, the rocks can emanate enough heat to confuse the onboard laser (used to determine the distance between the vehicle and a suspicious object). Worse, the rocks can occasionally retain so much heat that Miguel claims it can be hard to distinguish between a rock and a man's head (which is often the only part of the body he can see when a person is crouching down). This 'friction' offered by the environment, however, is not limited to the Moroccan shepherds, their animals and the humanoid rocks. Occasionally those trying to escape Miguel's gaze will use large squares of cardboard to hide their body heat from the camera. While this tactic works when they remain stationary, says Miguel, "when they move it looks like the whole mountain is moving!"

For the border guards operating SIVE's radar technology and cameras, they are aided by the fact that the system was specifically designed to cope with the environmental challenges posed by the marine environment 'under any circumstances' (Guardia Civil 2008, 59). Indeed the SIVE station in Algeciras, which controls the marine border between Barbate and Soto Grande, uses five separate radar stations. Together, explained Antonio (the on-site technician), their radar signals overlap and give the border guards reliable information on the speeds and directions of the myriad of vessels 
located in their search area. The radar is therefore an integral part of the SIVE system, offering what could be described as a God's Eye view of the marine area (see Haraway 1991; O’Tuathail 1996), making it theoretically possible for the border guards to spot a suspicious vessel at a distance of roughly $14 \mathrm{~km}$ from the coast (Indra 2016).

Despite the Guardia Civil's claims in their promotional material that the environment has been overcome through SIVE (and Antonio's similar assertions), however, the experiences of the border guards on duty tell a different story. Following Antonio's departure from the SIVE control room in Algeciras, the border guards on duty were quick to inform me of the difficulties they have when using the radar to search for and target migrant boats. Indeed, far from being able to remove and isolate the objects within their scopes (Weber 2005), the active terrain provides the guards with constant distractions. "The radar often gives us false readings," explained Eduardo, the senior border guard in the SIVE control room of Algeciras, "but it can really be from anything. Waves, whales, dolphins, fishing materials, they can all appear as something suspicious on the radar. One day I was monitoring this area here [points towards the area Algeciras' surveillance area closest to Morocco], and I saw some crazy readings coming from the radar. So I centred my camera to where I thought the readings were coming from and do you know what I saw? It was birds on their seasonal migration journey!" By performing the borderspace as a 
two-dimensional reality (Elden 2013), therefore, the radar screens were aimed at giving the guards a 'more-than-human vision' (Williams 2011) as the borderspace became flatter and more legible. Simultaneously, however, the radar removed the fixed, solid and benign appearances of the objects in its field of vision, giving them instead a threatening appearance through their indeterminacy (Budd and Adey 2009). In this way, the radar transforms the everyday natural occurrences of this marine environment, which might otherwise be considered beautiful to the naked eye, into 'suspicious' events that draw the guards' attention.

Operating the radar in Ceuta, despite the much smaller surveillance area, provided the guards with similar issues. Here, however, they were faced with a much greater problem, namely the radar's blind spots. Surprisingly for a system that had ostensibly been designed specifically for spotting small vessels at sea in difficult conditions, significant areas of the screen were effectively 'muted'. It transpired that the radar's blind spots included most of the area within one nautical mile off the coast due to the local vegetation, rocks and waves which could regularly trick the system. As a result, a slow boat travelling along the coast (a typical route used by migrants attempting the journey in the small, engine-less 'toy' boats) will be invisible to the 'God's Eye' of the radar. These spaces could, of course, be 'un-muted' (the sensitivity of the radar is set to pick up objects moving at a speed of two knots). This would, however, inundate the guards on 
duty with false alarms to the extent that the radar images would become illegible. By rendering the borderspace visible through techniques of flattening and by making what that which is geographically distant 'interactionally present' (Knorr and Bruegger 2002), therefore, the interactive screens used by the guards are not just sites upon which the borderspace is reproduced. In other words, the screens do not perform a border that exists independently of them (Hardie and MacKenzie 2006, 59), therefore, as instead they are one of its "conditions of possibility" that produce specific effects of cognition 
and action (Swanton 2013). It requires an experienced guard with significant know-how, therefore, to work with SIVE's agentic technologies.

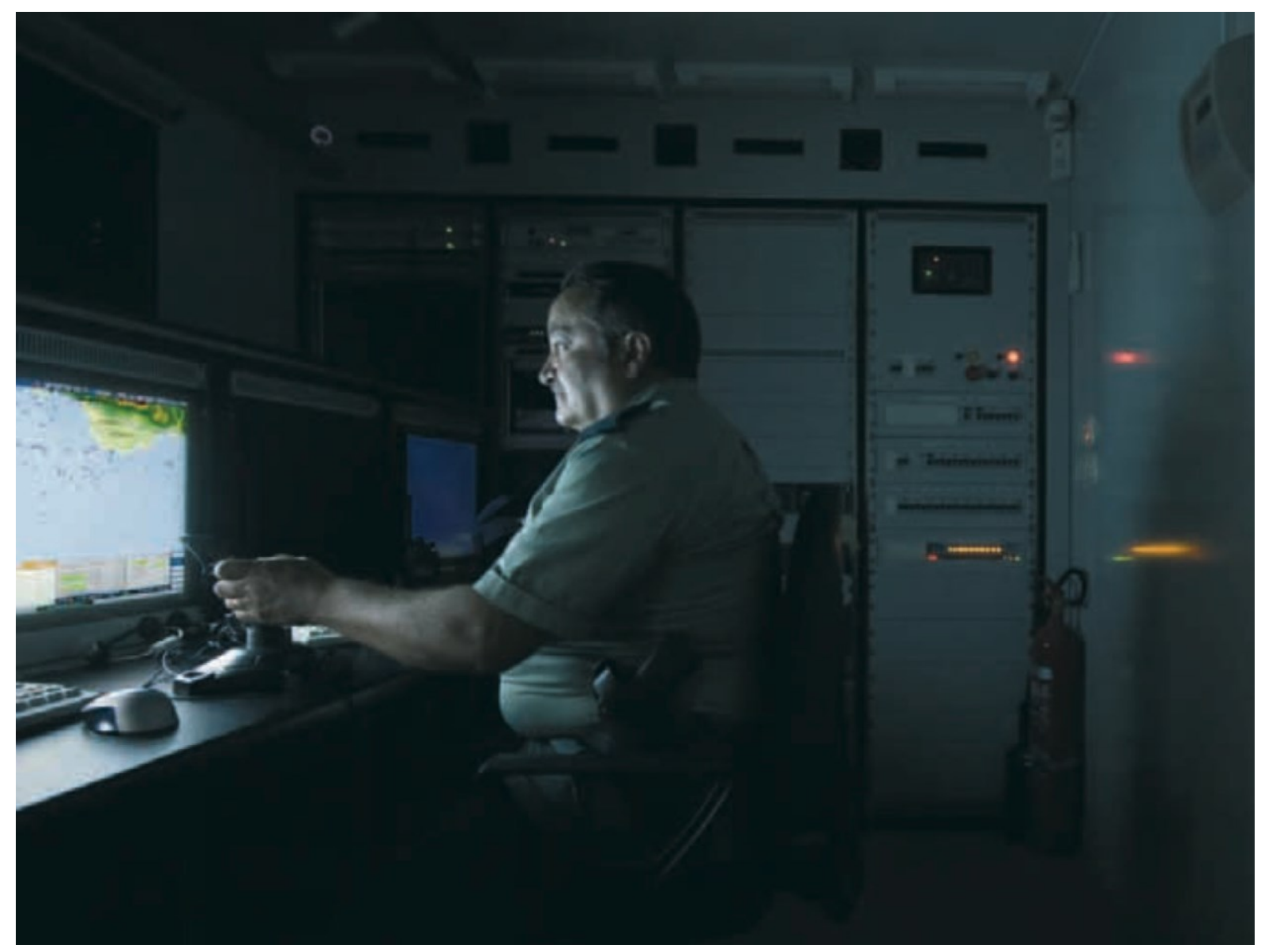

Figure 2 shows a stationary Guardia Civil officer manipulating SIVE's control systems while observing the screens for suspicious activity. Original caption reads: "One of the stations is controlled manually by a member of the Fiscal Service Patrol" (Guardia Civil, 2009, 106). Published with the permission of the Guardia Civil.

\section{BEHIND THE SCOPES}

As has already been made clear, in an effort to enable a 'more-thanhuman' vision (Williams 2011), the machine elements within the SIVE assemblage offer the border guards various multi-layered images (in 'realtime') such that the borderspace can be permanently made visible to the Guardia Civil (see Graham 2016). Yet as Williams (2011) has demonstrated 
concerning drone assemblages, "[w]hilst the requirement for there to be a human operator within the UAV assemblage remains, this desire for morethan-human vision is unmet" (Williams 2011, 386). While the vision produced through these assemblages might be technologically enhanced, therefore, "these visibilities are necessarily conditional [...] because they are not technical but rather techno-cultural accomplishments" (Gregory, 2011, 193 emphasis in original; see also Adey, 2010; Kaplan, 2006; Follis 2017). In other words, technologies can only 'see' what they have been designed to see - and they are based on the assumptions that have been made by their creators. In the context of SIVE and drones, moreover, responsibility still lies with the human eyes of border guards and soldiers to offer the final interpretation of the objects shown through the complex vision technologies. In discussing the limitations of the drone assemblage, Williams (2011) utilises Virillio's (1991) 'picnoleptic moment' to argue that the continual watching of the drone assemblage is partly outdone by the humans' inability to watch without blinking. While the drones' cameras might be able to offer a constant picture in 'real-time', therefore, the organic elements of the assemblage resist the possibility of achieving an unblinking vision (Williams 2011).

In the context of SIVE, however, both the human and machine elements suffer from their own forms of picnolepsy. Aside from detecting and projecting all 'unknown' objects as foreign and threatening, the radar only 'sees' 
objects that travel at a speed higher than two knots for a period of at least eight seconds. The radar's 'blinks', therefore, are regular and unavoidable. In terms of spotting most drug-smuggling activity this poses few problems as these are usually transported by speedboat (at a speed of 40 knots). Boats transporting migrants (either with old engines or none at all), by contrast, regularly travel at a speed between one and three knots and are, therefore, barely perceptible to SIVE's radar. Instead, a boat carrying migrants will most likely occur as an occasional blip on the radar screen (if it appears at all), rather than as a constantly detectable presence. The 'blip' would then have to be spotted immediately by the border guard on duty so that it could be investigated further by using the camera. Not only is the radar susceptible to its own version of picnolepsy, therefore, but the system demands the speedy cooperation between radar - (alert) guard - and camera if it is to function effectively. Aside from regularly filtering out false alarms, then, the border guards must also maintain an unbroken vision of the radar screen if they are to spot a 'blip' from a migrant boat.

Achieving this unbroken vision for the border guards, however, is far from guaranteed. To a certain extent the technologies have even hindered the guards' attempts at remaining vigilant. As with many forms of automation, the assumption has been made that technological solutions can replace the human actors of the system. Although the overall numbers of Guardia Civil 
border guards being sent to the border has increased in recent years, the number of guards in the SIVE control rooms in Ceuta and Algeciras has remained low. While in Ceuta I only ever observed one guard operating the SIVE cameras, three were on duty in Algeciras - although Eduardo and I were frequently the only ones in the room. The lived reality for the border guards in Algeciras, moreover, is that multi-task management means that their ability to ensure constant vigilance is limited. The command centre in Algeciras is also what the Guardia Civil refer to as a 'centro de mando $y$ control', meaning that it acts as a central node in the Guardia Civil's information network. Information from the surrounding area (concerning such things as fires and robberies) gets sent to the guard's computer terminal. There, the guard on duty manually filters it and the important information is sent on to the national coordination centre in Madrid. This information that needs to be filtered and passed on, in combination with other daily tasks (such as personal administrative work) and the random additional disturbances that occur throughout the day (telephone calls, everyday errands, nosy $\mathrm{PhD}$ students and other visitors), frequently create disturbances for the guards on duty. As a result, it is possible that at times there is no 'evervigilant' guard to watch the screens.

When the guards are able to dedicate their attention to the monitoring of the screens, they rely on SIVE's immensely powerful cameras to overcome the radar's aforementioned flaws. Indra, the company who designed SIVE, 
boast that during the day the system's cameras can detect a small boat at a distance of $20 \mathrm{~km}$, while at night this estimate is reduced to a (stillastonishing) $13 \mathrm{~km}$. Despite the quality of the images produced by the SIVE cameras, however, the information on the screens still requires a significant amount of experienced guesswork and 'know how' to interpret. For the 'trick', as it were, with vision technologies is not so much acquiring the power of sight, as it is acquiring the ability to view 'change' or deviance from the 'norm' (Graham and Wood 2003; Adey 2004; Scranton 2007; Amoore 2009; Graham 2010).While scanning the Moroccan hillside from the safety of the búho with his infrared camera, Miguel explains that migrants will sometimes purchase small fishing boats and mimic the movements of fisherman casting their nets at night. "I've never been fishing and I don't know how to fish," he said jovially, "but I know exactly what it looks like from a distance. I know the process, roughly how long it lasts and where it happens... just through operating this joystick!" In order to demonstrate his point, Miguel pointed the camera out into the dark bay at the small fishing boats in Moroccan waters. Miguel had monitored their movements when they first had first left the harbour in Fnideq, swapping regularly between observing the boats and the land area around the fence. "That one is a little suspicious though," he said zooming in on the boat furthest out in the bay, "it has no lights on and hasn't followed the circular route the fishermen usually take when they cast their nets." To my eyes, however, 
the pixels on the screen were barely recognisable as a boat, let alone a small fishing vessel with one or more people on board. Eventually Miguel turned the camera away from the boat, claiming that he would keep an eye on its position while conducting another scan of the area near the fence.

An associated difficulty with waiting for something out of the ordinary to happen in a situation such as the one described above is, of course, that while Miguel waited to see what the suspicious vessel might do, his eyes had been forced away from monitoring the land border. In the SIVE assemblage, only the radar can observe everywhere at once. While the cameras have a wide range when zoomed out and can be rotated at will, in order to spot and identify a migrant boat or group heading to the fence, the cameras often have to be utilised at full zoom. The result is that the guards' peripheral vision is almost entirely lost and, without the possibility of making use of their other senses, the areas outside the camera's zoomed vision become large blind spots. This frequently poses few problems as a broad sweep of a guard's area of responsibility takes little time and the guards frequently zoom out during checks. Occasionally, however, this rhythm of focused watching followed by broad sweeps is broken up by particular events requiring the guards' undivided attention. This is especially the case following the detection of a potential drug-smuggling attempt across the Strait. According to Eduardo, these moments can be the most stressful for 
the border guard on duty as they must coordinate an interception with the Guardia Civil's marine unit, as well as arrange for land-based units to intercept and search for other smugglers. On other occasions a boat carrying drugs will briefly become visible on the radar as it speeds towards Spanish waters, but will then disappear again as it waits for an opportune moment to make a drop. Throughout this time the guard on duty must use his camera to comb through the area in the hopes of spotting the boat before it makes its move.

For the border guards in the SIVE assemblage the decision to raise the alarm rests entirely with them and their knowledge of the borderspace. Yet those on duty both in Ceuta and Algeciras agreed that it can take a guard at least ten years to become proficient with the technology, to know the borderspace and to make speedy decisions based on what they can and cannot see. Not all border guards, moreover, have the same skill-sets as their colleagues. While some guards claim to be able to tell a subSaharan migrant from a Moroccan farmer through the infrared camera solely by the type of their clothing, others are considered to be better at spotting small movements a long way off and yet others are more proficient at overcoming the difficulties presented by the fog or cloud cover. In other words, the SIVE assemblage does not offer one singular controlling gaze over the borderspace. Instead, the geopolitical gaze of the Guardia Civil's surveillance technologies is performed through a multitude of unique gazes 
(Law 2002; Williams 2011). Beyond managing these numerous gazes, however, the 'success' of the system is also predicated on the achievement of swift interceptions by the Guardia Civil's allies in the borderspace. A challenge I turn to in the following section.

\section{ALLIANCES AND BREAKAGES}

"The border is like a chewing gum," proclaimed Lucas in Ceuta's SIVE station, referring to the constant, unpredictable pressures exerted on the border. While Lucas' chewing gum analogy, of course, meant that everything could change from one day to the next, 'tomorrow' also happened to be Ramadan. None of the Guardia Civil officers in the SIVE control room knew how Ramadan was going to affect their work, even though it was a religious festival none of them would be observing. They suspected it might in fact ease the pressure on the border, as most of the migrants making the border crossing attempts are Muslim. Similarly there might also be fewer small fishing vessels out in the bay, as people would be eating with their families at night and saving their energy during the day - meaning fewer boats to monitor. The opposite, however, could also be true. The Guardia Civil officers were concerned that their Moroccan counterparts might tire during their month of fasting and become less watchful. Indeed, the Guardia Civil officers were candid on their reliance on the 'clean up' operations (literal translation) conducted by their Moroccan counterparts in 
the nearby forest. "Otherwise we'd be completely overrun with them," grumbled Lucas. In other words, SIVE and the border fence are the border assemblage's last line of defence, rather than the first. The complex array of these vision technologies are, therefore, only employed in Ceuta on the people who have already made it passed the tight control of the Moroccan border guards.

The Moroccan patrol boats, however, are also crucial to the functioning of the SIVE system, should a migrant boat manage to evade the attentions of the Moroccan guards on the land before setting off. If a guard in the Ceuta control room spots a migrant boat through either SIVE's camera or the radar, he immediately notifies the Guardia Civil's patrol boat, the Salvamento Marítimo and the Moroccan forces (with whom they have a direct link). The Guardia Civil's patrol boat will accompany the Salvamento Marítimo rescue boat if the migrant vessel is located in Spanish waters, intervening only in an emergency and if the vessel in distress is in Spanish waters. $^{4}$ In Moroccan waters, by contrast, the Moroccan patrol boat or rescue service would be expected to 'rescue' the migrant vessel (regardless of its level of distress) and bring the migrants back to Morocco - whereupon they can often experience severe beatings and occasionally face transportation hundreds of miles from the border. As a result, the SIVE vision technologies are often used by the Guardia Civil in Ceuta to circumvent the international non-refoulement agreement. Occasionally, however, the system breaks down 
and the actors in Morocco fail to act. This can occur if the Moroccan patrol boats are already engaged in other activities and if the Salvamento Marítimo fail to establish contact with the Moroccan rescue services. In such cases the Salvamento Marítimo is required to enter Moroccan waters to rescue the migrant vessel and return it to a Spanish port. In other words, speed, alongside the ability to see in 'real time', is essential to the proper functioning of the border assemblage.

Drawing on Virilio's (1994) visions of the increasing speed of modern warfare, the border between Ceuta and Morocco can therefore be found less in a particular line to be defended and rather in the time required for the Guardia Civil to spot a migrant boat and coordinate an interception with the Moroccan authorities. The extent to which the system functions in 'real time' is regularly tested to its limits as guards operating the SIVE technologies must spot and notify the Moroccan patrol of a migrant vessel long before it can reach Spanish waters. The quick responses of the Spanish and Moroccan border guards can be contrasted against previous, high-profile, boat migration events that managed to captivate peoples' attentions during the time it took for governments to organise a response. Examples of these include the Tampa and the SIEVX in Australian waters in 2001 (Budz 2009) and the 'left-to-die-boat', which was ignored in the Mediterranean by NATO forces (Pezzani and Heller 2013). The speed on which the system in Ceuta is based means that, unlike these high-profile 
cases, there is increasingly less time for politics to occur between a boat being spotted and a state's response (Virilio 1994; 2005; Bartram 2004). Prior to my visit to the SIVE station in Algeciras I had assumed the guards there would follow a similar protocol to that of their colleagues in Ceuta. Indeed, Antonio, the Amper technician, appeared to confirm as much when I asked him why the guards on duty did not appear to be fully engaged in searching for migrant boats. "It's the wrong time of day," he explained, "if you had come around 6am you would have seen the guards watching the screens, carefully searching for the pateras." This assertion was later, however, contradicted by Eduardo and his colleague, José, who claimed that pateras could reach their surveillance areas at any time of day. "We do try and search for pateras in Moroccan waters with the cameras sometimes," explained José, "but it's incredibly difficult [...] When using the infrared camera you're searching for this tiny heat source, and sometimes you confuse it with a dead pixel on the display." While ostensibly, therefore, the guards in Algeciras could use the cameras and radar technology to notify the Moroccan guards of inbound migrant vessels, in practice these aren't spotted by the guards in the station until they have reached international waters between Spain and Morocco - at which point neither the Moroccan patrol boats nor their rescue service are likely to react. Aside from tackling drug smugglers whose boats are detectable via the radar, therefore, the SIVE station in Algeciras can for now 'only' be 
used for the detection and rescue of migrant boats beyond Moroccan waters. Despite the Guardia Civil's aim of 'pinching space' (see Serres and Latour 1995) in order to enact the border well beyond Spanish territorial waters through SIVE, therefore, only the SIVE station in Ceuta was capable of doing so.

Occasionally, however, the system breaks down as a result of the external actors $f$ the Guardia Civil's direct control. In the first four months of 2014, for example, the number of successful border crossing attempts between Morocco and Spain shot up to $2,800,{ }^{5} 130 \%$ more than for the same period the year before (Frontex 2014). The Frontex Risk Analysis (2014) avoided mentioning the cause of the increased border crossings, mentioning only that the Spanish Guardia Civil had warned of increasing numbers of migrants in the makeshift camps near the enclaves of Ceuta and Melilla. Eduardo, however, was much more scathing in his assessment of what had happened it January 2014. "It all depends on the Moroccan King," he said, "if he's happy, the Moroccan guards will do their jobs. But if Morocco wants something from the EU, such as more money [from the EU European Neighborhood Policy], then he'll use the migrants to bargain with. We had 1,200 migrants arrive in just 72 hours last year... That was not increased migrant pressure, it was the Moroccan guards telling them to go!" Despite the expenses invested in SIVE, therefore, the European border assemblage is almost entirely dependent on the cooperation of the Moroccan 
army and its work in the hills of Northern Morocco. Though SIVE can only 'see' beyond the borders of the EU, the actors of the border assemblage spread beyond it. In fact, the assemblage extends to within the boats used by the migrants. Unlike the wooden or inflatable toy boats bought by the smugglers and used by the migrants, the old motors used to propel these vessels can sometimes be used by the Guardia Civil to track the smuggler gangs in Morocco. In order to reduce the danger to themselves, therefore, migrants are warned by the smugglers that the Guardia Civil will prosecute the captain (or the whole crew) of a boat with a motor and that the Spanish will be able to see them through the cameras. It has, therefore, become common practice for migrants to throw their engines overboard after leaving Moroccan waters and to wait until they are spotted by the SIVE system. While it is unknown if this has contributed to any migrant deaths in Ceuta, in 2013 a patera off the coast of Lanzarote was rammed at high speed by a Guardia Civil patrol boat after the 'captain' of the patera had abandoned the engine and rudder for fear of being prosecuted as a smuggler (Ferrer-Gallardo and van Houtum 2014). ${ }^{6}$ There are two points to be made here. Firstly, broadening of the border assemblage to include the objects that migrants need to reach Europe has in this respect further endangered the lives of those attempting to make the crossing. Secondly, the changing tactic of the migrants and smugglers demonstrates the roles that their agency plays in the formation of the borderspace and how this, 
in turn, will affect the ways in which the Guardia Civil can perform the border. There is no way of knowing, for example, if migrants might soon be convinced to employ the same tactics in attempts at reaching mainland Spain, where they could find themselves trapped in the major shipping lanes or pushed off course due to the strong currents. In broadening the border assemblage to include the objects that migrants need to reach Europe, therefore, the lives of those attempting to make the crossing have become further endangered.

A second interesting development concerning the case in Lanzarote, however, was the fact that the recordings from the SIVE cameras were obtained by a local news station and used to invalidate the Guardia Civil's initial account of what had happened (Ferrer-Gallardo and van Houtum 2014). Similarly, in an infamous case of 15 deaths occurring in the sea area alongside the border crossing point of El Tarajal, Guardia Civil recordings were obtained by NGOs and the Spanish media. It was hoped that the Guardia Civil security recordings, either from SIVE cameras, or from the security cameras on the border would provide evidence firstly of where the deaths had occurred (the Guardia Civil claimed they had died in Moroccan waters) and secondly, whether or not the Guardia Civil had fired rubber bullets and smoke canisters at the drowning men. ${ }^{7}$ While in both cases the Guardia Civil were eventually exonerated by the Spanish courts (the case in Ceuta supposedly because of the poor image quality of the security recordings), ${ }^{8}$ 
these two exceptional events do demonstrate the lack of total control exerted by the Guardia Civil over the actors in the border assemblage. The cameras of the Guardia Civil, it would seem, watch both ways.

If the circumstances surrounding the Guardia Civil's loss of control over the actors in the assemblage were exceptional, however, the border guards face a similar struggle on a daily basis. Just as the Guardia Civil are not always the sole users of the security recordings, so too can the Salvamento Marítimo be called by the migrants at sea or NGO groups who learn of their departure. Examples of NGO groups that are having a strong effect on the border assemblage include 'the Alarm phone' and 'WatchtheMed.net'. The first offers a hotline that migrants can phone at sea in an emergency, the volunteers then contact the nearest rescue services and track the boat's recovery. Linked to this, 'WatchtheMed.net' is an online mapping platform that catalogues and monitors boat distress calls and positions them within the correct search and rescue zones and operational areas. The group uses the accounts of survivors and witnesses, but also the analysis of ocean currents, winds, mobile phone data, satellite imagery and vessel AIS in order to spatialise events at sea. Through this spatialisation, the complex legal and political geography of the sea is made visible such that ongoing events at sea can be monitored in near 'real time' in an attempt to bring governments and rescue agencies to account should they fail to enact a SAR mission in their area or in cases where coastguards have been accused of pushing migrant boats back into non-European 
waters (see Dijstelbloem et al 2017). The use and manipulation (through 'mission creep') of vessel AIS and satellite data is, therefore, not a tactic solely limited to border agencies. Pezzani and Heller $(2013,294)$ call this challenge to the God's Eye view of European surveillance a 'Disobedient Gaze', "which aims not to disclose what the regime of migration management attempts to unveil clandestine migration; but unveil that which it attempts to hide - the political violence it is founded on and the human rights violations that are its structural outcome." The effect of this Disobedient Gaze is hard to quantify, although to date, WatchtheMed has published the details of over 700 cases in which they were informed of one more vessels in distress - almost all of which were saved by the relevant authority. The real success of the initiative, writes Tazzioli (2016, 576), comes in its 'twisting' of the politics of visibility; the capacity to detect has now become the "inescapable duty of rescue." While Virillio's (1994, 205) phrase "the tyranny of real time" is becoming increasingly apt for those attempting to remain undiscovered from Europe's surveillance gaze, therefore, it is increasingly also being made applicable to those behind the scopes. Indeed, in Ceuta the effect of the group's actions was perhaps best be summed up by Lucas during our first discussion in the enclave's Guardia Civil's headquarters, when I asked if he could describe SIVE: "Have you heard of a water taxi service?" 


\section{CONCLUSION: BECOMING MULTIPLE}

Rather than focusing on the European border as a whole, this paper has sought to put assemblage theory to work in order to unpack a single 'border assemblage': the Guardia Civil's SIVE border surveillance system. Specifically my aims were to question how the various human and machine elements of SIVE combine to form a totalising vision over the borderspace and perform the border, as well as determine the humanitarian effects of this surveillance. I have shown that SIVE sometimes acts as a 'humanitarian' border control system and that its vision is susceptible to 'blinks' and rebellions. Yet what is important here is why the system is susceptible and only how it oscillates between enacting the border beyond the limits of territory and becoming a tool for search and rescue. Moreover, in stating my aims as I have done above, I have made three mistakes. In this concluding, therefore, section I will set out what these errors are, how they have been negated in the above analysis and reflect upon how they might inform border studies and critical work on security and surveillance more broadly.

Firstly, there is no single SIVE assemblage of which we can speak, rather it is multiple (see Mol 2002). As Sohn $(2015,184)$ highlights, "a wall circumscribing a territory may signify a protection against external dangers for some, an obstacle or a symbol of political oppression for others, a scene for artistic expression (e.g. a graffiti board) for others". Moreover, 
multiple ontologies of thought can coexist simultaneously in the performances of the border (Steinberg and Peters 2015). While the images produced by the Guardia Civil (2008) in their promotional material concerning SIVE perform it as being an all-seeing, pervasive system that functions through the perfect cooperation between man and machine, the everyday realities for the border guards tell a different story; one in which they must wrestle with dead pixels, cameras that occasionally fail and 'muted' spaces. Neither of these performed versions of SIVE is more real than the other, rather they simply coexist (Law and Urry 2004). While the first is performed towards EU decision-makers and other border agencies, the second exerts power upon migrants at the territorial borders of Spain. Indeed as Kaplan (2006) argues in the context the US' World War II military campaign, although the need to achieve precision bombing was not supported by evidence, this did not stop the bombardier becoming a heroic figure in popular culture or reduce the number of industries "pressed into the quest for high-tech solutions to the perceived need for precision."

Even the everyday realities of what SIVE is and how it performs the border, however, vary to such a degree across time and space that yet more fragmentations of SIVE come into being. While SIVE functioned in Ceuta to perform the border by alerting the Moroccan navy to migrant boats still within Moroccan waters, SIVE in Algeciras is predominantly equipped for targeting speedboats carrying drugs and initiating Search and 
Rescue operations for migrant boats that have already made it into Spanish waters. The multiplicities of SIVE extend further still, however, as the ways in which the system performs its surveillance is formed by the variations in the skills of the human border guards operating the machines. In other words, SIVE is as multiple as the unique pairs of eyes that 'see' through it (see Williams 2011; Law 2002). This paper, therefore, calls for more attentiveness to the multiplicities of not just the border as a whole, but also the various systems of control that perform it and to think through how they co-exist, silence each other and influence both policy and the unfolding of everyday geopolitics.

The second error originates from the misplaced assumption that I would be able to isolate SIVE and the actors that comprise it from other actors and assemblages present within the borderspace. Or that I should want to. Considering SIVE was designed to provide marine surveillance, for example, this article has focused heavily on the challenges posed by the rocky environment that surrounds the border fences of Ceuta for the border guards in the mobile búhos. While these challenges would be written out of analyses focused solely on the 'formal performances' of SIVE, here they tell a vital story concerning the everyday performance of the border. Indeed the mobile búhos play an important part in the surveillance of the marine border around Ceuta (especially near Benzú where there is no radar coverage), yet the guards' tasks in these surveillance stations are inhibited 
by the need to simultaneously monitor the terrain around the fences. Meanwhile, in Algeciras, monitoring the SIVE cameras is only one of the guards' many daily duties; all of which take up time and remove eyes from the not-so-ever-vigilant machines. In terms of identifying the cracks and fissures within surveillance systems (Walters 2011; Pötzsch 2015), therefore, assemblage theory finds them in the moments and spaces where actors are simultaneously committed to numerous assemblages. In the case of SIVE, this limit is accentuated by the need for speed which drives the performance of the border through the swift interactions between machines, Spanish border guards and Moroccan navy. Yet this requires all of these actors to cooperate at all times (an issue discussed below). This inability of actors to fully commit to SIVE, therefore, poses questions for further study of other surveillance and military systems. In particular, it raises the importance of foregrounding both the lived and environmental contexts in which security and military actors are situated and how these inhibit or alter everyday performances of (in)security and warfare.

The third error comes from referring to SIVE as 'the Guardia Civil's border assemblage'. Doing so implies full control over the assemblage by one particular actor, as opposed to the distribution of power that was discussed previously. This is of course not to say that power is distributed equally amongst the actors involved, yet the system is nevertheless susceptible to various forms of rebellion or unpredictability. Specifically this paper has 
focused on the ways in which the camera recordings in both Lanzarote and at El Tarajal have been used by pressure groups to accuse the Guardia Civil of wrongdoings. Although the Tarajal case brought against the Guardia Civil has now been rejected twice by the Spanish courts, ${ }^{9}$ nevertheless the footage showing Guardia Civil firing around 145 rubber bullets (made visible by tell-tale splashes) and 5 gas canisters at swimming/drowning migrants in both Spanish and Moroccan waters has caused widespread media interest and outrage in Spain. ${ }^{10}$ Similar to the \#NotABugSplat campaign, ${ }^{11}$ therefore, hyper-visibility (generated in part through technologies of surveillance) is being utilised as a resistance tactic. To talk of the border assemblage as being the Guardia Civil's to control, moreover, is to negate the roles played by the Moroccan navy and the Salvamento Maritimo in the ways in which the marine border is performed. While the cooperation with the Salvamento Marítimo gives SIVE legitimacy as a border control technology that saves lives at sea, it is only with the help of the Moroccan navy that that the border assemblage prevents migrants from entering Spanish waters. Finally, asserting such primacy to the Guardia Civil in the production of the borderspace is to obscure its volatility. As Andersson (2016) has previously shown concerning the fortification of the border fences, for example, the introduction of new technologies can have unpredictable effects not only on the way the border is managed but also in how it is encountered and resisted by those on the move. In this case, the current 
reaction to SIVE by the migrants has been to increase their vulnerability due to the belief that 'captains' will be prosecuted. There is no telling, therefore, how the border might change in the near future. While the Guardia Civil's literature on SIVE suggests a near total control over the borderspace granted through SIVE's vision capabilities, the border guards on the ground know that that the status quo could shift at any time. In other words, an important challenge in future work on borders and surveillance will be to further follow the actors 'on the ground' in order to determine the extent of surveillance assemblages' (overlapping) networks such that potential cracks might be found. It is the 'little things' (Thrift 2000) which force the God's Eye to blink... and it is in the blink of an eye that the borderspace can change.

\section{REFERENCES}

Alarm Phone. (2017). In solidarity with Migrants at Sea! The Alarm Phone Three Years On. Available at: https://alarmphone.org/en/campaigns/in-solidarity-with-migrantsat-sea-the-alarm-phone-3-years-on/

Ajana, B. (2013). Governing through Biometrics: the biopolitics of identity. Basingstoke: Palgrave Macmillan. 
Amicelle, A., Aradau, C., \& Jeandesboz, J. (2015). Questioning security devices: Performativity, resistance, politics. Security Dialogue, 46(4), 293-306.

Amoore, L. (2006). Biometric borders: Governing mobilities in the war on terror. Political Geography, 25(3), 336-351.

Amoore, L. (2009). Algorithmic war: Everyday geographies of the war on terror. Antipode, 41(1), 49-69.

Anderson, B., Kearnes, M., McFarlane, C., \& Swanton, D. (2012). On assemblages and geography. Dialogues in Human Geography, 2(2), 171-189.

Anderson, B., \& McFarlane, C. (2011). Assemblage and geography. Area, 43(2), 124127.

Andersson, R. (2014). Illegality, Inc.: Clandestine migration and the business of bordering Europe. University of California Press.

Andersson, R. (2016). Hardwiring the frontier? The politics of security technology in Europe's "fight against illegal migration." Security Dialogue, 47(1), 22-39.

Adey, P. (2010). Aerial Life: Spaces, Mobilities, Affects. Chichister: Wiley-Blackwell.

Bellanova, R. \& Duez, D. (2016). The Making (sense) of EUROSUR: How to control the sea borders? In: R. Bossong, \& H. Carrapico (Eds), EU borders and shifting internal security: Technology, externalization and accountability (23-44). Switzerland: Springer International Publishing.

Bennett, J. (2010). Vibrant matter: A political ecology of things. Durham, NC: Duke University Press.

Bartram, R. (2004). Visuality, dromology and time compression: Paul Virilio's New Ocularcentrism. Time \& Society, 13(2-3), 285-300.

Barry, A. (2014). Material Politics: Disputes along the Pipeline. Chichister: WileyBlackwell.

Bialasiewicz, L. (2012). Off-shoring and Out-sourcing the Borders of EUrope: Libya and EU Border Work in the Mediterranean. Geopolitics, 17(4), 843-866.

Bigo, D. (2002). Security and Immigration: Toward a Critique of the Governmentality of Unease. Alternatives, 27(1), 63-92.

Bigo, D. (2014). The (in)securitization practices of the three universes of EU border control: Military/Navy - border guards/police - database analysts. Security Dialogue, 45(3), 209-225. 
Boyce, G. A. (2016). The rugged border: Surveillance, policing and the dynamic materiality of the US/Mexico frontier. Environment and Planning D: Society and Space, 34(2), 245-262.

Brambilla, C. (2015). Exploring the critical potential of the borderscapes concept. Geopolitics, 20(1), 14-34.

Budd, L., \& Adey, P. (2009). The software-simulated airworld: Anticipatory code and affective aeromobilities. Environment and Planning A, 41(6), 1366-1385.

Budz, M. (2009). A heterotopian analysis of maritime refugee incidents. International Political Sociology, 3(1), 18-35.

Cote-Boucher, K., Infantino, F., \& Salter, M. B. (2014). Border security as practice: An agenda for research. Security Dialogue, 45(3), 195-208.

DeLanda, M (2006). A new philosophy of society: Assemblage theory and social complexity. New York: Continuum.

Deleuze, G., \& Guattari, F. (1987). A thousand plateaus: Capitalism and schizophrenia. Translated by B. Massumi. London: Athlone.

Dijstelbloem, H., Van Reekum, R., Schinkel, W. (2017). Surveillance at sea: The transactional politics of border control in the Aegean. Security Dialogue, 48(3), 224-240.

Dittmer, J. (2014). Geopolitical assemblages and complexity. Progress in Human Geography, 38(3), 385-401.

Elden, S. (2013). Secure the volume: Vertical geopolitics and the depth of power. Political Geography, 34, 35-51.

European Commission (2008). Press release: External Borders Fund 2007-2013 Spain. IP/08/1849 (1 December 2008). http://europa.eu/rapid/press-release_IP-081849_en.htm?locale=en

European Parliament and Council of the European Union (2013) 'Regulation (EU) No 1052/2013 of the European Parliament and of the Council of 22 October 2013 establishing the European Border Surveillance System (Eurosur)'. L295/11. 6 November.

Ferrer-Gallardo, X., \& Van Houtum, H. (2014). The deadly EU border control. ACME: An International E-Journal for Critical Geographies, 13(2), 295-304.

Follis, K. S. (2017). Vision and transterritory: The borders of Europe. Science, Technology, \& Human Values, 1-28. 
Frontex. (2014). Frontex Risk Analysis Report (Q1). Warsaw. http://frontex.europa.eu/assets/Publications/Risk_Analysis/FRAN_Q1_2014.pdf

Godenau, D. (2014). Irregular maritime immigration in the Canary Islands: Externalization and communautarisation in the social construction of borders. Journal of Immigrant \& Refugee Studies, 12(2), 123-142.

Graham, S. (2011). Cities under siege: The new Military Urbanism. London and New York: Verso.

Graham, S. (2016). Vertical: The city from satellites to bunkers. London and New York: Verso.

Gregory, D. (2011). The everywhere war. The Geographical Journal, 177(3), 238-250.

Guardia Civil. (2008). SIVE: Cinco años vigilando la frontera.

Haggerty, K. D., \& Ericson, R. V. (2000). The surveillant assemblage. The British Journal of Sociology, 51(4), 605-622.

Haraway, D. (1991). Simians, cyborgs, and women: The reinvention of nature. New York: Routledge.

Hardie, I., \& MacKenzie, D. (2007). Assembling an economic actor: The agencement of a hedge fund. The Sociological Review, 55(1), 57-80.

Heller, C., \& Jones, C. (2014). Eurosur: Saving lives or reinforcing deadly borders? Statewatch Journal, 23(3), 9-12.

Hyndman, J. (2004). Mind the gap: Bridging feminist and political geography through geopolitics. Political Geography, 23(3), 307-322.

Jacobs, J. M. (2006). A geography of big things. Cultural Geographies, 13(1), 1-27.

Johnson, C., Jones, R., Paasi, A., Amoore, L., Mountz, A., Salter, M., \& Rumford, C. (2011). Interventions on rethinking "the border" in border studies. Political Geography, 30(2), 61-69.

Kaplan, C. (2006). Precision targets: GPS and the militarization of U.S. consumer identity. American Quarterly, 58(3), 693-713.

Knorr Cetina, K., \& Bruegger, U. (2002). Global microstructures: The virtual societies of financial markets. American Journal of Sociology, 107(4), 905-950.

Law, J. (2002). Aircraft stories: Decentering the object in technoscience. Durham and London: Duke University Press.

Law, J., \& Urry, J. (2004). Enacting the social. Economy and Society, 33(3), 390-410. 
López-Sala, A. (2015). Exploring dissuasion as a (geo)political instrument in irregular migration control at the southern Spanish maritime border. Geopolitics, 20(3), 513534.

Meehan, K., Shaw, I. G. R., \& Marston, S. A. (2013). Political geographies of the object. Political Geography, 33, 1-10.

Mol, A. (2002). The body multiple: Ontology in medical practice. Durham and London: Duke University Press.

Nail, T. (2017). What is an assemblage? SubStance, 46(1), 21-37.

Ó’Tuathail, G. (1996). An Anti-geopolitical Eye: Maggie O’Kane in Bosnia, 1992-93. Gender, Place \& Culture, 3(2), 171-186.

Pallister-Wilkins, P. (2015). The humanitarian politics of European border policing: Frontex and border police in Evros. International Political Sociology 9(1), 53-69.

Parker, N., \& Vaughan-Williams, N. (2009). Lines in the Sand? Towards an Agenda for Critical Border Studies. Geopolitics, 14(3), 582-587.

Parker, N., \& Vaughan-Williams, N. (2012). Critical Border Studies: Broadening and Deepening the "Lines in the Sand" Agenda. Geopolitics, 17(4), 727-733.

Pezzani, L., \& Heller, C. (2013). A disobedient gaze: Strategic interventions in the knowledge(s) of maritime borders. Postcolonial Studies, 16(3), 289-298.

Pötzsch, H. (2015). The emergence of iBorder: Bordering bodies, networks, and machines. Environment and Planning D: Society and Space, 33(1), 101-118.

Rajaram, P. K., \& Grundy-Warr, C. (2007). Introduction. In: P. K. Rajaram, \& C. Grundy-Warr (Eds), Borderscapes: Hidden geographies and politics at territory's edge (ix-xl). Minneapolis and London: University of Minnesota Press.

Rijpma, J., \& Vermeulen, M. (2015). EUROSUR: Saving lives or building borders? European Security, 24(3), 454-472.

Rumford, C. (2006). Theorizing Borders. European Journal of Social Theory, 9(2), 155169.

Salter, M. B. (2013). To Make Move and Let Stop: Mobility and the Assemblage of Circulation. Mobilities, 8(1), 7-19.

Scott, J. C. (2009). The Art of Not Being Governed: An anarchist history of upland southeast Asia. New Haven, CT: Yale University Press. 
Secor, A. J. (2001). Toward a Feminist Counter-geopolitics: Gender, Space and Islamist Politics in Istanbul. Space and Polity, 5(3), 191-211.

Serres, M. \& Latour, B. (1995) Conversations on Science, Culture and Time, Ann Arbor Ml: University of Michigan Press.

Shaw, I. G. R. (2012). Towards an evental geography. Progress in Human Geography, 36(5), 613-627.

Slesinger, I. (2018). A Cartography of the Unknowable: Technology, Territory and Subterranean Agencies in Israel's Management of the Gaza Tunnels. Geopolitics, $a(0), \quad 1-26$.

Sohn, C. (2015). Navigating borders' multiplicity: The critical potential of assemblage. Area, 48(2) 183-189.

Steinberg, P., \& Peters, K. (2015). Wet ontologies, fluid spaces: Giving depth to volume through oceanic thinking. Environment and Planning D: Society and Space, $33(2), \quad 247-264$.

Sundberg, J. (2011). Diabolic Caminos in the Desert and Cat Fights on the Río: A Posthumanist Political Ecology of Boundary Enforcement in the United StatesMexico Borderlands. Annals of the Association of American Geographers, 101(2), 318-336.

Swanton, D. (2013). The steel plant as assemblage. Geoforum, 44, 282-291.

Tazzioli, M. (2016). Eurosur, Humanitarian Visibility, and (Nearly) Real-time Mapping in the Mediterranean. ACME: An International E-Journal for Critical Geographies, 15(3), $561-579$.

Thrift, N. (2000). It's the Little Things. In: K. Dodds \& D. Atkinson, (Eds), Geopolitical Traditions: A century of geopolitical thought. London: Routledge (p380-387).

Virilio, P. (1991). The aesthetics of disappearance. New York: Semiotext(e).

Virilio, P. (1994). Bunker archaeology. New York: Princeton Architectural Press.

Virilio, P. (2005). Negative horizon: An essay in dromoscopy. London and New York: Continuum.

Vukov, T., \& Sheller, M. (2013). Border Work: Surveillant assemblages, virtual fences, and tactical counter-media. Social Semiotics, 23(2), 225-241.

Walters, W. (2006). Border/Control. European Journal of Social Theory, 9(2), 187-203. 
Walters W, (2011). Rezoning the global: technological zones, technological work and the (un-)making of biometric borders. In: V. Squire, (Ed), The Contested Politics of Mobility: Borderzones and Irregularity (pp. 51 - 73). London: Routledge.

Walters, W. (2014). Drone Strikes, Dingpolitik and Beyond: Furthering the Debate on Materiality and Security. Security Dialogue, 45(2), 101-118.

Williams, A. J. (2011). Enabling persistent presence? Performing the embodied geopolitics of the Unmanned Aerial Vehicle assemblage. Political Geography, 30(7), 381-390.

1 The automatic identification system (AIS) is an automatic tracking system used on ships and by vessel traffic services(VTS) for identifying and locating vessels by electronically exchanging data with other nearby ships, AIS base stations, and satellites.

2 The identities of all the Guardia Civil guards in this paper have been anonymised.

3 Please note, these figures only include funding from the EU's External Borders Fund that were specifically allocated to SIVE ('EU contribution'), spending on the border fences for example was therefore not included. For a full breakdown of the contributions towards SIVE by year: http://www.interior.gob.es/en/web/servicios-alciudadano/programa-de-solidaridad-union-europea/programa-de-solidaridad-union-europeaenglish-ver/external-borders-fund

4 Although some migrants in the enclave's detention centre accused Guardia Civil patrol boats of blocking their way to Spanish waters while waiting for Moroccan forces to arrive. Although Lucas did show me a picture on his phone of a migrant boat being apprehended by Moroccan forces (observed from a Guardia Civil patrol boat), I have no way of ascertaining the accuracy of these claims.

5 http://www.20minutos.es/noticia/2273960/0/inmigrantes-melilla-ceuta/valla-saltos/ceti-cie/

6 http://canariassemanal.org/not/7559/la_patrullera_de_la_guardia_civil_arrollo_a_la_patera_en_lanzarote_video_I

7 http://www.elmundo.es/sociedad/2015/10/15/561f9524e2704e6e518b45e2.html

8 Ibid.

9 https://www.eldiario.es/desalambre/archiva-quince-inmigrantes-muertos-

Tarajal_0_733527236.html

10 https://www.eldiario.es/catalunya/documental-desmonta-Gobierno-Tarajal-

TV3_0_601590152.html

11 https://notabugsplat.com/ 